\title{
The Impact of Market Assessment on The Sustainability of Humanitarian Projects in Yemen: INGOs Perspective
}

\author{
Naif Ahmed Morshed ${ }^{1}$, Mohammed Saleh Al-Abed ${ }^{2}$ \\ ${ }^{1}$ Lebanese International University, Sana'a, Yemen \\ ${ }^{2}$ Impact Research Center, Sana'a, Yemen \\ Correspondence: Naif Ahmed Morshed, Lebanese International University, Sana'a, Yemen. E-mail: \\ murchednaif@gmail.com \\ Received: December 28, 2020 \\ Accepted: January 10, 2021 \\ Online Published: January 10, 2021 \\ doi: 10.48110/joi.v1i1.21 \\ URL:https://doi.org/ 10.48110/joi.v1i1.21
}

\begin{abstract}
Sustainability of humanitarian projects has increasingly become an important theme that all INGOs, donors, fundraisers, beneficiaries, and stakeholders are focusing on in the time being. However, some humanitarian projects in Yemen have been suffering from the lack of sustainability. This study aims to examine the impact of market assessment on the sustainability of humanitarian projects in Yemen from the perspective of international NGOs. Quantitative approach was employed, and questionnaires were used to collect data from nine INGOs in Yemen; namely OXFAM, Handicap, Care, ACF, NRC, DRC, Islamic Relief, Save Children and Acted. The sample comprises of 207 participants, out of which $168(81.16 \%)$ responded. The results indicate that there is a significant strong positive correlation between market assessment and the sustainability of humanitarian projects in Yemen. In addition, the results show that market assessment explain $84.1 \%$ of the sustainability of humanitarian projects. Furthermore, market assessment has a significant impact on the sustainability of humanitarian projects. Necessarily, projects management should take market assessment as critical aspect along all the stages of projects cycles starting from need assessment to project designing, proposal development, planning, implementation and monitoring and finally in review and evaluation, the time of project closure, and lesson learned. If not, the sustainability of projects in Yemen will continue to be problematic and cause loose of satisfaction of beneficiaries and trust of donors. Similarly, all project staff should be aware of market developments around them, including the access to the market, concentration of the markets, availability and cost of required goods, accessibility by buyers and sellers to the market, and most importantly integration of several markets. Therefore, the design of the projects will be based on the practical points that will help to ensure the budget allocated and the best quality of response. Finally, the design of the projects should be built on lesson learned from previous projects in the same context and same experience in the thematic and geographic areas that have the full market assessment summaries.
\end{abstract}

Keywords: Market Assessment, Humanitarian Projects, Sustainability of Projects, Humanitarian Assistance, Yemen

\section{Introduction}

The rationale of fundamental humanitarian assistance is to help people in need, the beneficiaries. There are two principles guiding humanitarian operations. First, "those affected by disaster or conflict have a right to life with dignity and, therefore, a right to assistance; and second, all possible steps should be taken to alleviate human suffering" (Sphere Association, 2018 p. 15). However, humanitarian assistance has been criticized for its ineffectiveness at a macro- economic level. Even, it has been condemned for constraining development. Conversely, other investigations demonstrate that aid can contribute to economic development. However, the results differ according to geographical location and policy (Haavisto \& Kovács, 2014). In both theory and practice, the discussion of the effectiveness of humanitarian assistance has ultimately been filtered down to the operational level, leading humanitarian organizations to focus on cost and time efficiency as well as transparency. However, there has been additional criticism for overlooking equity, customer service, and sustainability(Haavisto \& Kovács, 2014). All these aspects are essential for aligning the operational with the longer-term objectives of humanitarian aid. Simultaneously, several large donors have incorporated long-term objectives into their requirements of Humanitarian Organizations (HOs), obliging them to consider the persistence of their impact in project planning (Haavisto \& Kovács, 2014). 
Nonetheless, the long-term impacts of aid are difficult to monitor and evaluate. It is not even clear which impacts should be included in such an ecological assessment, and how exactly HOs should consider them. HOs have been criticized for shortsightedness in supply chain design (Haavisto \& Kovács, 2014). However, they have started to overcome some of that criticism by using local suppliers to empower local communities. Conversely, donor requirements, which otherwise are used to drive standards of accountability, efficiency and effectiveness are yet to pay more attention to sustainability (Haavisto \& Kovács, 2014).

Policy makers, donors, projects managers, and communities often face challenges in sustaining seemingly worthwhile projects, especially in low-income and middle-income countries. Most concerns about sustainability are related to premature discontinuation of projects after an initial period of support. In addition to the needs left unmet, discontinued projects are waste of human, monetary, and technical start-up investments, and they can diminish beneficiaries trust and support for future projects. Many studies of humanitarian projects in low-income and middle-income countries have sought to identify the factors associated with sustainability, but the data have not been reviewed systematically. Furthermore, several divergent conceptual approaches exist but their basis in empirical research has not always been articulated.

In Yemen, HOs have similar challenge but they look at it from a different perspective. INGOs in Yemen have been available since 1984, and before this date, they were doing some humanitarian aids with limited fund. In 2015 and after the conflict outbreak, INGOs enhanced the response in many different sectors including food security and livelihood, shelters, water \& sanitation, health care, nutrition projects, and some other projects related to peacebuilding and youth empowerment. According to OCHA Pledging event report (2018), international donors pledged more than US\$2.9 billion to support the delivery of urgently needed humanitarian aid to millions of people in Yemen. Moreover, the United Nations Fund Conference in 2019 secured \$2.6 billion (€2.3 billion) in pledges to aid millions of people facing starvation in war-torn Yemen (OCHA, 2018). During the crises of Yemen conflict, humanitarian actors have become major role players in providing basic needs and welfare to Yemeni society. In fact, humanitarian projects represent important part of supporting Yemeni society despite some shortcomings. There is a wide admission of the contributions they bring to many families, and there are some needs for their continued existence (OCHA, 2018).

Nevertheless, humanitarian projects in Yemen were criticized by the local authority and other stakeholders, as millions of USD has been spent but no sustainable impact has been seen among the targeted beneficiaries (BBC News). According to Yemen Humanitarian Update report, May 2020, still 24 million people in Yemen are in need for urgent humanitarian assistance (OCHA, 2020). In addition, OCHA Humanitarian needs overview (2015) stated that only 21.1 millions of Yemeni people are in need for some humanitarian assistance (OCHA, 2015). The comparison between the two reports of the same UN humanitarian lead agencies in Yemen reveals that there is no sustainable impact on the target beneficiaries during the 5 years of conflict. The reason is that humanitarian projects in Yemen provide saving lives impacts, which disappear as soon as the project closed. Humanitarian agencies have delivered too many different types of projects, which include emergency and resilience projects in many sectors (food security, water \& sanitation, cholera response projects, nutrition projects, protection projects, health projects, and shelters projects). Those projects have targeted almost all segments of society (woman, men, girls, and boys) and have mostly focused on vulnerable people affected by the conflict including women, children, elderly people with special needs, and marginalized people.

Although more than 3 billion of total assistance is recorded in the year 2018 as per UN humanitarian update, $86 \%$ of Yemeni people are still in acute need for assistance. Furthermore, DW news TV channel released an article about the criticism of INGOs working in Yemen stated that UN agencies spent around 3 billion USD in 2019, while $80 \%$ of Yemeni people are still suffering from hunger (DW, 2018). Most of criticism was about ignoring sustainability as essential aspects of aligning operational with long term objectives (Haavisto \& Kovacs, 2014). According to the Sphere Standard (2018), the conflict-affected people have the right to assistance and all possible steps should be taken to alleviate human suffering from disaster or conflict. Consequently, international assistance and all humanitarian agencies including donors, UN agencies and other sub agencies have done a considerable achievement during the last 5 years of the war.

In the context of donor-funded development programs and projects, sustainability can be defined as the continuation of benefits after major assistance from a donor has been completed/withdrawn (Okun, 2009). The Brunt land Commission memorably defined sustainability in its report (Our Common Future) in 1987 as the "development that meets the needs of the present generation without compromising the ability of future generations to meet their own needs" (World Bank, 2005 p. 21).

Despite the large number of studies that adapted suitability and addressed some factors affecting the achievement of sustainability, no study has been done to examine the relationship between market assessment and the sustainably of humanitarian projects. For the purpose of understanding the factors that may affect the sustainability 
of humanitarian projects, this study focuses on market assessment as a main factor that could contribute to the sustainability. Market assessment is a detailed and objective evaluation of the potential of a new product, new business idea or new investment.

\section{Literature Review}

\subsection{Sustainability of Projects}

According to Weerawardena, McDonald and Mort (2009), sustainability is the ability to perform and deliver the project benefits to the target groups after funding from donor terminates. Okun (2009) defined project sustainability as continuation of benefits after major assistance from a donor has been completed/withdrawn. In summary, sustainability means the ability to last long. In this study, we will take the sustainability of humanitarian projects based on the above definitions that lead to the meaning.

Sustainability of humanitarian projects has become an important theme that all the INGOs, donors, fundraisers, beneficiaries, and stakeholders are highlighting on in the time being. In UNDP, it is considered as one of the four pillars of its mandate. UNICEF follows UNDP and discusses it mostly from ecological perspective as sustainable land management. Other organizations discuss sustainability in a vague manner, but the latent content analysis helps to reveal more details for their understanding.

Recently, several large donors have incorporated their long-terms objectives to the requirements of humanitarian NGOs, which has obliged them to consider the sustainability of projects impacts on program planning (Aid \& Civil Protection department of the European Commission 2010; USAid, 2012). Further increase in the awareness of long term has been adapted by UNDP theory of the change (Unicef strategic plan 2018-2021). UNHCR stated that there is no other option to enhance resilience among refugees across the world unless there is a real support of the concept of sustainable livelihood, which refers to an income-generating activity that results in a positive return on investments sufficient to provide an income and fund and further investments necessary to continue that activity (Lois, \& Chessex 2013).

Based on the above statements by donors and humanitarian response agencies, the sustainability consideration study has become immense and necessary to find appropriate solution to continuity in Yemen. Sustainability in humanitarian projects has very important benefits and can achieve many goals: (1) ending poverty and hunger; (2) better quality of education and healthcare; (3) better water quality and better sanitation; (4) gender equality; (5) and more jobs and stronger economies (Sustainable Development Group, 2019). United Nations have developed a paper called (Transforming our world) as agenda for 2030 sustainable development, in which they stated that by using sustainability, all countries benefit by having a healthy and well-educated workforce with the knowledge and skills needed for productive and fulfilling work and full participation in society (Desa, 2016).

Sustainability will strengthen the productive capacities of the least developed countries in all sectors, including structural transformation. Sustainability means the increase of productive capacities, productivity and productive employment, financial inclusion, sustainable agriculture, pastoralist and fisheries development, sustainable industrial development, universal access to affordable, reliable, sustainable and modern energy services, sustainable transport systems, and quality and resilient infrastructure (Desa, 2016). When it comes to sustainability and factors influencing the sustainability of humanitarian programming, we find a large number of studies but most of them are related to different effects and different perspectives. For instances, Ira Haavisto stated that most humanitarian agencies have been criticized by donors for not enhancing the efficiency of expenditures and their projects not having sustainable impact (Haavisto \& Kovács, 2014).

Kunza and Goldb (2015) proposed a framework of sustainable humanitarian Supply Chain Management (SCM), which facilitates disaster response, aims to help as many people as possible, and requires comprehensive performance. Another important study by Okun (2009) examines the factor affecting the sustainability of donorsfunded projects in Kenya. Okun (2009) stated that development projects, which are initiated and/or funded by donor agencies, perform poorly, and many projects become non-operational on termination of donor support. In this case, Okun (2009) came up with two key factors that may enhance the sustainability and ability to continue the delivery of the project. According to Okun (2009), the two key factors that affect the sustainability of donorfunded projects are the existing donor policies and the management systems adopted by the project. Whereas, the Department for International Development (DFID) developed their own sustainable livelihood approach, in which they related sustainability to the need analysis, planning, prioritizing, implementing and monitoring.

\subsection{Market Assessment}

Market assessment is a detailed and objective evaluation of the potential of a new product, new business idea or new investment (Asian Enterprise Institute, 2013). It is a comprehensive analysis of environment forces, market 
trends, entry barriers, competition, risks, and opportunities that may affect the humanitarian works. Whether you are thinking of venturing into a new market or launching a new product, conducting a marketing assessment is a crucial first step in determining whether there is a need or a potential customer base for your product (Asian Enterprise Institute, 2013). Market systems, both formal and informal, can protect livelihoods by supplying productive items such as seeds and tools (Julliard, 2018). A well-executed market assessment enables humanitarian agencies to decide where to use limited resources and to go after markets and opportunities that will provide the best returns on investments.

Most of the world's population relies on markets to cover at least a portion of its basic needs. In the humanitarian sector, Market-Based Programming (MBP) is increasingly becoming a routine option in large part due to the increased uptake of Cash Transfer Programming (CTP) across sectors. As a result, humanitarian organizations have progressively focused on understanding markets to determine the most appropriate response and modality. Humanitarian organizations are recognizing both their role as market actors and the importance of the impact they can have on markets, especially for the crisis-affected population with whom they are working. Humanitarian responses, delivered either through CTP or in-kind, should be market-sensitive and protect livelihoods, local jobs and businesses. They can even support markets, bridging the gaps between short-term relief interventions and medium- to long-term market development initiatives. To do so, humanitarian responses need to be informed by proper market assessment and analysis, starting at the design stage. Market analysis should hence be considered a key element of response analysis (Sivakumaran, 2011).

Market assessment and market analysis support the design of based programming. For example, some INGOs use the local markets to deliver the project, as supporting the local market can create more jobs to local people and enhance the sustainability among them, which requires thorough market assessments (Julliard, 2018). In addition, in market-based programming, some INGOs support the market functionality and rehabilitate or construct the infrastructures that help the buyers and sellers to have access to the local market, which helps to enhance the sustainability of local people, but this also requires comprehensive market assessments (Julliard, 2018). Failure to conduct proper market assessment could result in wastage of resources, missed opportunities, poor returns on investments, and even substantial financial losses, which could be detrimental to the future of your company (Asian Enterprise Institute, 2013).

From humanitarian perspectives, markets are critical drivers of recovery and resilience. The ability of crisisaffected populations to meet their needs through local markets is a key pre-condition of effective cash transfer programming. Therefore, decision-making on cash transfer programming requires market assessment as a key component of response analysis to inform the design and implementation of appropriate interventions. Improving capacity in market analysis directly enables Global Objective \#2 (Ensuring cash is routinely considered, alongside other tools) of the Global Framework for Action by Cash Learning Partnership (CLP, 2017).

According to WFP (2018), market assessment is very important because it helps plan for the type of intervention. It assures no negative impact on the intervention and helps to develop sustainable solution for the food crises. It can also help to understand the capacity of local markets, which consequently helps humanitarian workers to apply sustainability through local markets (WFP, 2018). In the book of refugees' economies, interventions that aim to promote refugees' sustainable livelihoods must be based on a sound and comprehensive understanding of existing markets and the private business sectors within which refugees are making a living (Betts et al., 2014).

In almost all societies today, including those in crisis, markets are a key determinant of household livelihoods and resilience. Market outcomes are a significant determinant of livelihood outcomes. Therefore, understanding how crises affect markets and market relations is critical to understanding livelihoods and both humanitarian and development outcomes (Levine, 2017). Levine (2017) talked about the importance of market assessment to identify potential response and improve aids delivery. Levine (2017) also stated that market assessment has proved useful to contribute to the strategy and planning of assistance.

Julliard (2018) in her book (minimum standards for market analysis) defined market assessment, but she referred it to collecting market-related data to understand the key features and characteristics of a market system or the impact a disaster could have on the market system. She focused on the market assessment and its importance in market-based programming, which is considered as one of the response modalities and helps the sustainability of crises-effected societies. But she didn't indicate the role of market assessment for the sustainability of humanitarian projects, which has too many advantages like ensuring the availability of required goods for any sustainable construction or ensuring the long-lasting impacts of projects.

Nutz (2017) talked briefly about the market assessment, the vital roles of markets to the lives of refugees and IDPs, how market protects the livelihood of people, how market-based response helps people in the immediate aftermath of a disaster. She also explained the significance of market assessment in determining the type of 
response. She explained some tools and guidance on markets assessment.

\subsection{Market Assessment and Sustainability}

Market assessment is a significant concept within the context of the World Humanitarian Summit held in May 2016 and the successful agreement of the sustainable development goals (Sustainable Development Group, 2019). Humanitarian agencies including both donors and implementers have been increasingly recognizing the major role of markets in achieving not only sustainable economic development but also higher impact humanitarian responses.

Additionally, gaps between needs and funding widen. There are several calls to enhance cost efficiency and effectiveness and provide opportunities to improve humanitarian assistance (Center for Global Development, 2015). Markets are an integral part of people's lives, and people are an integral part of markets, so humanitarian responses do not only need to be designed with a good understanding of key markets but can also relate markets understanding to the sustainability of their response.

Some UN agencies do not only assess the markets, but also adapt projects to support local market system to ensure resilience and sustainability of the crises-effected people. OXFAM Great Britain has developed evidence synthesis protocol called (influence of market support intervention on households food security), in which market assessment and sustainable livelihood for the households, either in crises or not, increase relationship that leads humanitarian organizations to increasingly incorporate market assessments in their assessment protocols and response analysis frameworks (Vince, 2016).

Understanding how affected people are dependent on the environment for their own recovery can also inform programme design and lead to more sustainable responses to cope with future shocks and reduce future risk (Sphere Association, 2018)). The same story exists for water and sanitation projects. Organizations cannot build, construct, or rehabilitate a long-lasting water projects unless there is a fully addressed market assessment to all affecting market forces (Sphere Association, 2018). Accordingly, this study developed the following hypothesis.

\section{H1: Market Assessment has a significant impact on the sustainability of humanitarian projects in Yemen.}

The research employed the quantitative approach and it was designed using a causal method, as the main goal is to identify the cause and effect relationship between market assessment factor and the sustainability of humanitarian projects implemented by INGOs operating in Yemen. This is because the fact that in causal or explanatory research (Krishna, 2013), cause and effect relationships between variables are explored (Sekaran, 2000). The causal research is a more appropriate method, as the functional relationship between the effect predicted on the dependent variable and the causal factors is under investigation (Hair, Black, \& Babin, 2010). In addition, hypothesis testing design was used as it offers understanding of the relationships that occur among variables. The measurement of the market assessment factor was adapted from Multi-sector market assessment companion, guide and tool kits with thirty-nine items.

\section{Methods}

Self-administered questionnaire was developed and focuses on the INGOs working in Yemen, which were chosen as the data sources. This study targeted the employees who are working in nine INGOs work on humanitarian projects in Yemen; namely; OXFAM, Handicap, Care, ACF, NRC, DRC, Islamic relief, Save Children, and Acted. The total populations was 449 employees working at that selected INGOs in Yemen and according to Krejcie and Morgan (1970), the sample size was 207. Based on the research problem and objectives, the convenience sampling method was applied. The respondents at the INGOs were asked to fill the questionnaire by email and WhatsApp via known coordinators in each INGO.

In this research the sample random method is used to ensure the various subgroups of the targeted population which are defined in the chosen sample list that represents the whole targeted.

In this study, analyzing the demographic information (gender, age, education level, job position and experience) was carried out via frequency analysis. For the gender participants response was $68.45 \%$ males verses 31.55 females. The age of them classified into four Characteristics; $25.60 \%$ respondents are aged less than 30 years old; $69.64 \%$ respondents between 30 and 40 years old; $4.17 \%$ respondents between 41 and 50 years old; and $0.60 \%$ respondent over 50 years old.

The education of respondents who have diploma are $1.19 \%, 59.52 \%$ respondents have bachelor degree; $35.71 \%$ respondents have a master degree; $1.19 \%$ respondents have a $\mathrm{PhD}$ degree; and $2.38 \%$ respondents have other level of education.

Regarding the job position, $8.33 \%$ respondents are program managers; $5.36 \%$ respondents are program 
coordinators; $11.90 \%$ respondents are team leaders; $18.45 \%$ respondents are senior officers; $30.95 \%$ respondents are officers; $13.10 \%$ respondents are assistants; and $11.90 \%$ respondents are having other job position title.

Regarding the experience, $5.36 \%$ respondents have less than 2 years of experience; $35.71 \%$ respondents have between 2 and 5 years of experience; $40.48 \%$ respondents have between 6 and 10 years of experience; and $18.45 \%$ respondents have over 10 years of experience.

\section{Findings}

Out of 207 persons, a total of 168 respondent were responded which represented $82 \%$ of total sample size. Once the required numbers of respondent's samples of the distributed questionnaires were gathered, the data were analyzed by SPSS software. All variables' items were evaluated based on a 5-point scale. Table 1 shows a summary for the descriptive statistics of all variables in descending order, which indicates that thirty-nine items used to measure the market assessment (MA) factor have a mean of 2.66 (Neutral); 17 items used to measure the sustainability of humanitarian projects (SHP) factor have a mean of 2.34 (Disagree).

Table 1 Summary of the Descriptive Statistics

\begin{tabular}{lllll}
\hline & Mean & Std. Deviation & Percentage & Verbal \\
\hline Market Assessment (MA) & 2.66 & 0.99 & $53.21 \%$ & Neutral \\
Sustainability of HPs (SHP) & 2.34 & 1.13 & $46.76 \%$ & Disagree \\
\hline
\end{tabular}

Under the descriptive statistics of market assessment, Table 2 shows that item 11 (We assess the availability of core goods available in the target markets) gets the first rank with a mean of 3.87 (Agree), and a standard deviation of 1.39. Item 27 (We assess the accessibility of the goods needed in the quality and quantity required in their reference market places) ranks second with a mean of 3.64 (Agree), and a standard deviation of 1.47. Item 19 (We assess the characteristics of wholesalers in local markets) ranks the lowest (thirty-ninth) with a mean of 2.02 (Disagree), and a standard deviation of 1.29. The average of the items of variables is 2.66 (Neutral), and the standard deviation is 0.99 .

Table 2 Descriptive Statistics of Market Assessment Items

\begin{tabular}{|c|c|c|c|c|}
\hline & $\mathbf{N}$ & Mean & $\begin{array}{l}\text { Std. } \\
\text { Deviation }\end{array}$ & Verbal \\
\hline $\begin{array}{l}1 \text { We assess the availability of core goods available in the } \\
\text { target markets. }\end{array}$ & 168 & 3.78 & 1.39 & Agree \\
\hline $\begin{array}{l}2 \text { We assess the accessibility of the goods needed in the } \\
\text { quality and quantity required in their reference market } \\
\text { places. }\end{array}$ & 168 & 3.64 & 1.47 & Agree \\
\hline $\begin{array}{l}3 \text { During market assessment we identify some core goods to } \\
\text { be assessed. }\end{array}$ & 168 & 3.61 & 1.46 & Agree \\
\hline $\begin{array}{l}4 \text { We summarize the main market places used by the majority } \\
\text { of people of concern. }\end{array}$ & 168 & 3.36 & 1.45 & Neutral \\
\hline $\begin{array}{l}5 \text { We identify places people come from (community, villages, } \\
\text { IDPs camps etc). }\end{array}$ & 168 & 3.32 & 1.36 & Neutral \\
\hline $\begin{array}{l}6 \text { We consider the monetary value change throughout the } \\
\text { goods flow. }\end{array}$ & 168 & 3.26 & 1.29 & Neutral \\
\hline $\begin{array}{l}7 \text { During the pre-assessment we have d upon strategic } \\
\text { programme plan for all humanitarian response in the area of } \\
\text { intervention for the near future. }\end{array}$ & 168 & 3.24 & 1.33 & Neutral \\
\hline $\begin{array}{l}8 \text { During pre-assessment we ensure target population needs is } \\
\text { specified, documented and prioritized. }\end{array}$ & 168 & 3.23 & 1.38 & Neutral \\
\hline $\begin{array}{l}9 \text { We consider strengthening markets to provide a sustainable } \\
\text { source of poverty prevention. }\end{array}$ & 168 & 3.13 & 1.41 & Neutral \\
\hline 10 We identify the security status in the market place. & 168 & 3.08 & 1.25 & Neutral \\
\hline $\begin{array}{l}11 \text { We completely review the updated context before doing any } \\
\text { market assessment. }\end{array}$ & 168 & 3.00 & 1.38 & Neutral \\
\hline $\begin{array}{l}12 \text { We select project materials based on last updated market } \\
\text { assessment. }\end{array}$ & 168 & 2.97 & 1.40 & Neutral \\
\hline $\begin{array}{l}13 \text { We use key informants interviews and focus group } \\
\text { discussions during the market assessment. }\end{array}$ & 168 & 2.92 & 1.33 & Neutral \\
\hline
\end{tabular}




\begin{tabular}{|c|c|c|c|c|}
\hline & $\mathbf{N}$ & Mean & $\begin{array}{l}\text { Std. } \\
\text { Deviation }\end{array}$ & Verbal \\
\hline $\begin{array}{l}14 \text { We use recent assessment of priority needs of households } \\
\text { and individuals within households before doing any } \\
\text { assessment. }\end{array}$ & 168 & 2.89 & 1.29 & Neutral \\
\hline $\begin{array}{l}15 \text { We identify the financial services available in the } \\
\text { marketplace that could support an intervention. }\end{array}$ & 168 & 2.72 & 1.46 & Neutral \\
\hline $\begin{array}{l}16 \text { We describe how population were affected due to crises in } \\
\text { past } 6 \text { months. }\end{array}$ & 168 & 2.71 & 1.34 & Neutral \\
\hline $\begin{array}{l}17 \text { During pre-assessment we prepare summary of the } \\
\text { humanitarian situation for coming } 6 \text { months. }\end{array}$ & 168 & 2.60 & 1.31 & Disagree \\
\hline $\begin{array}{l}18 \text { It is important to identify the direction in which the goods } \\
\text { flow from the producer to the end consumer. }\end{array}$ & 168 & 2.58 & 1.47 & Disagree \\
\hline $\begin{array}{l}19 \text { We analyze the capacity of local markets to meet needs of } \\
\text { population. }\end{array}$ & 168 & 2.52 & 1.54 & Disagree \\
\hline $\begin{array}{l}20 \text { We investigate what alternative specifications are available } \\
\text { for each core good. }\end{array}$ & 168 & 2.52 & 1.44 & Disagree \\
\hline $\begin{array}{l}21 \text { We determine goods transportation links between the } \\
\text { market and other markets. }\end{array}$ & 168 & 2.51 & 1.47 & Disagree \\
\hline $\begin{array}{l}22 \text { We know how core goods can be supported in the current } \\
\text { situation. }\end{array}$ & 168 & 2.46 & 1.43 & Disagree \\
\hline $\begin{array}{l}23 \text { We usually find how core prices changed in the past } 12 \\
\text { months. }\end{array}$ & 168 & 2.43 & 1.39 & Disagree \\
\hline $\begin{array}{l}24 \text { My organization systematically carry out market analysis to } \\
\text { determine the appropriate forms of assistance. }\end{array}$ & 168 & 2.39 & 1.47 & Disagree \\
\hline $\begin{array}{l}25 \text { We analyze the constraints in the market environment or } \\
\text { infrastructure that could prevent the suppliers from } \\
\text { increasing the quantity of goods supplied. }\end{array}$ & 168 & 2.38 & 1.52 & Disagree \\
\hline $\begin{array}{l}26 \text { We assess the time when there is a shortage in core goods in } \\
\text { local markets. }\end{array}$ & 168 & 2.36 & 1.40 & Disagree \\
\hline 27 We identify the goods that traders could not supply. & 168 & 2.34 & 1.40 & Disagree \\
\hline $\begin{array}{l}28 \text { We always analyze the integration of and competition } \\
\text { between core good suppliers. }\end{array}$ & 168 & 2.33 & 1.45 & Disagree \\
\hline $\begin{array}{l}29 \text { We know well who can help for better understanding of the } \\
\text { market. }\end{array}$ & 168 & 2.30 & 1.39 & Disagree \\
\hline $\begin{array}{l}30 \text { We do market assessments and capacities of government } \\
\text { and other actors before respond to needs. }\end{array}$ & 168 & 2.27 & 1.28 & Disagree \\
\hline $\begin{array}{l}31 \text { We collect full information about the market including type } \\
\text { of the market, frequency of the market days, distance to the } \\
\text { market, cost to travel to the markets and condition of the } \\
\text { market. }\end{array}$ & 168 & 2.24 & 1.45 & Disagree \\
\hline $\begin{array}{l}32 \text { Risks associated with a market-based response, and } \\
\text { mitigation measures are always addressed during the market } \\
\text { assessment. }\end{array}$ & 168 & 2.24 & 1.36 & Disagree \\
\hline $\begin{array}{l}33 \text { During the assessment we are able to explain why the } \\
\text { number of people visit market increase/decrease within last } \\
12 \text { months. }\end{array}$ & 168 & 2.15 & 1.29 & Disagree \\
\hline 34 We assess the characteristics of suppliers in local markets. & 168 & 2.08 & 1.38 & Disagree \\
\hline $\begin{array}{l}35 \text { We have the authority to change the specification of } \\
\text { materials based on market result. }\end{array}$ & 168 & 2.07 & 1.28 & Disagree \\
\hline 36 We assess the characteristics of suppliers in local markets. & 168 & 2.04 & 1.45 & Disagree \\
\hline 37 We assess the role of markets authority. & 168 & 2.04 & 1.34 & Disagree \\
\hline 38 We assess the characteristics of retailers in local markets. & 168 & 2.04 & 1.27 & Disagree \\
\hline $\begin{array}{l}39 \text { We assess the characteristics of wholesalers in local } \\
\text { markets. }\end{array}$ & 168 & 2.02 & 1.29 & Disagree \\
\hline Market Assessment (MA) & 168 & 2.66 & 0.99 & Neutral \\
\hline
\end{tabular}


Under the descriptive statistics of the sustainability of humanitarian projects, Table 3 shows that item 6 (We consider fair distribution of benefits among target people is necessary for sustainable result of our project) gets the first rank with a mean of 3.17 (Neutral), and a standard deviation of 1.34. Item 4 (We ensure no harm to the environment as a result of our projects) ranks second with a mean of 2.77 (Neutral), and a standard deviation of 1.34. Item 15 (We usually ensure the long-lasting profitability of our projects) ranks the lowest (fifth) with a mean of 1.96 (Disagree), and a standard deviation of 1.36. The average of the items of variables is 2.34 (Disagree), and the standard deviation is 1.13 .

Table 3 Descriptive Statistics of Sustainability of Humanitarian Projects

\begin{tabular}{|c|c|c|c|c|c|}
\hline & & $\mathbf{N}$ & Mean & $\begin{array}{l}\text { Std. } \\
\text { Deviation }\end{array}$ & Verbal \\
\hline 1 & $\begin{array}{l}\text { For me, respect beneficiaries' opinion and cultures is } \\
\text { necessary to have sustainable result for my projects. }\end{array}$ & 168 & 3.17 & 1.34 & Neutral \\
\hline 2 & $\begin{array}{l}\text { We insure no harm to the environment as a result of our } \\
\text { projects. }\end{array}$ & 168 & 2.77 & 1.34 & Neutral \\
\hline 3 & $\begin{array}{l}\text { Target people benefit from the products of our projects results } \\
\text { more the benefiting from the result itself. }\end{array}$ & 168 & 2.71 & 1.28 & Neutral \\
\hline 4 & $\begin{array}{l}\text { Population trends(growth/migration) is considered during the } \\
\text { implementation of our projects. }\end{array}$ & 168 & 2.56 & 1.33 & Disagree \\
\hline 5 & $\begin{array}{l}\text { Beneficiaries are well trained to maintain the outputs after } \\
\text { projects closure. }\end{array}$ & 168 & 2.35 & 1.35 & Disagree \\
\hline 6 & $\begin{array}{l}\text { We enhance efficiency and effectiveness in the use of projects } \\
\text { results (for ex using water solar pump rather than fuel } \\
\text { generators or use local products rather than importing. }\end{array}$ & 168 & 2.30 & 1.44 & Disagree \\
\hline 7 & $\begin{array}{l}\text { Project team in my organization ensure a well-planned exit } \\
\text { strategy and hand over of projects activities to local } \\
\text { community. }\end{array}$ & 168 & 2.26 & 1.39 & Disagree \\
\hline 8 & $\begin{array}{l}\text { We consider reduce of the poverty among target people as } \\
\text { priority objective for my projects. }\end{array}$ & 168 & 2.24 & 1.50 & Disagree \\
\hline 9 & $\begin{array}{l}\text { Our projects rehabilitate renewable, reliable and extendable } \\
\text { natural resources. }\end{array}$ & 168 & 2.20 & 1.37 & Disagree \\
\hline & $\begin{array}{l}\text { Our projects caused improved standards of lives for target } \\
\text { people. }\end{array}$ & 168 & 2.18 & 1.37 & Disagree \\
\hline & $\begin{array}{l}\text { Our projects have specific measures to ensure the target } \\
\text { people wellbeing for long period in the future. }\end{array}$ & 168 & 2.18 & 1.32 & Disagree \\
\hline & $\begin{array}{l}\text { Our projects focus on capacity building \& train the } \\
\text { beneficiaries how to generate income. }\end{array}$ & 168 & 2.16 & 1.43 & Disagree \\
\hline & $\begin{array}{l}\text { One of our project objectives is to increase the number of } \\
\text { producers to be higher than consumers. }\end{array}$ & 168 & 2.01 & 1.31 & Disagree \\
\hline & $\begin{array}{l}\text { We consider fair distribution of benefits among target people } \\
\text { is necessary for sustainable result of our project. }\end{array}$ & 168 & 2.01 & 1.42 & Disagree \\
\hline & $\begin{array}{l}\text { We insure to achieve gender equality \& women empowerment } \\
\text { during our projects implementation. }\end{array}$ & 168 & 1.98 & 1.27 & Disagree \\
\hline & $\begin{array}{l}\text { Beneficiaries are well trained to maintain the outputs after } \\
\text { projects closure. }\end{array}$ & 168 & 1.96 & 1.36 & Disagree \\
\hline & ustainability of Humanitarian Projects (SHP) & 168 & 2.34 & 1.13 & Disagree \\
\hline
\end{tabular}

The relationship between the factors (Market Assessment and Sustainability of humanitarian projects) was tested using Pearson Correlation, as tabulated in Table 4. The results indicate that there is a significant strong positive correlation between Market Assessment (MA) and Sustainability of Humanitarian Projects (SHP) $(r=+0.884, p=$ $0.000)$

Table 4 Correlation Result

\begin{tabular}{llll}
\hline & & MA & SHP \\
\hline \multirow{3}{*}{ MA } & Pearson Correlation & 1 & $.884^{* *}$ \\
& Sig. (2-tailed) & & 0.000 \\
SHP & $\mathrm{N}$ & 168 & 168 \\
\hline
\end{tabular}




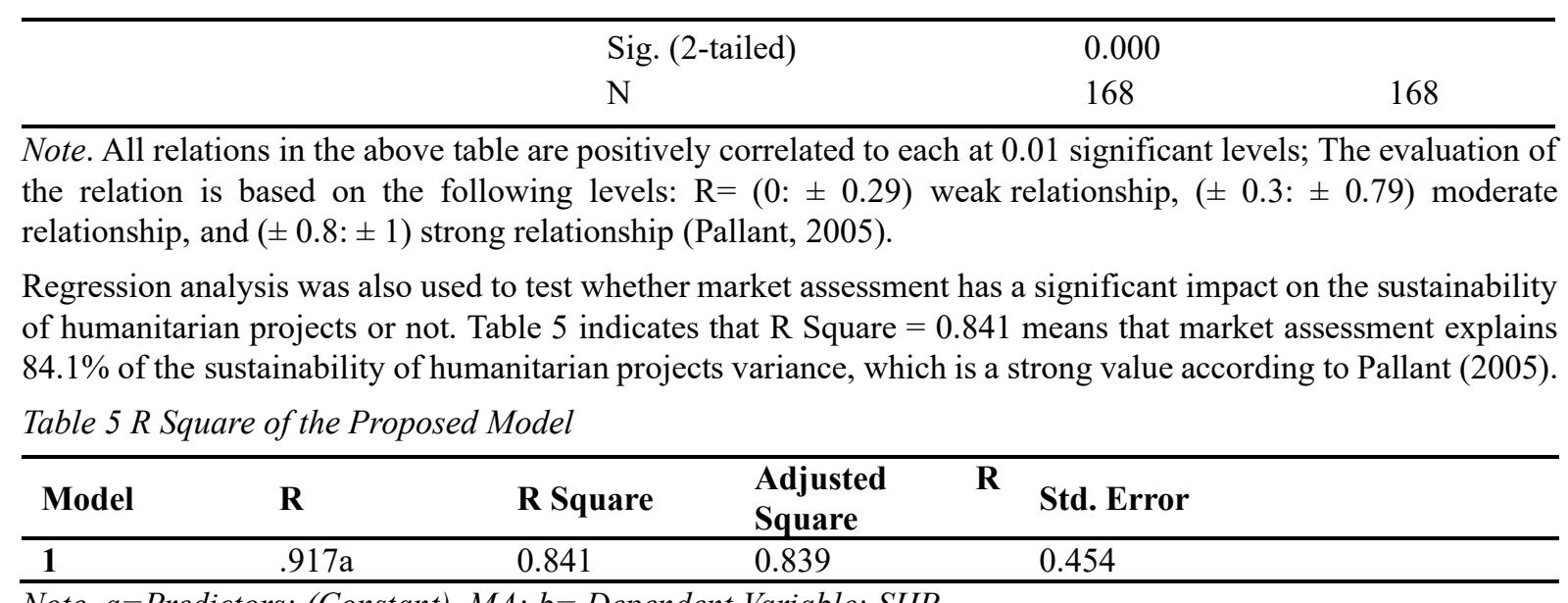

Note. $a=$ Predictors: (Constant), $M A ; b=$ Dependent Variable: SHP

Table 6 shows the result of ANOVA test. It shows that the result $(F$ test $=435.207$; at Sig. $=0.000)$ indicates a strong significant relationship between the sustainability of humanitarian projects as dependent variable and the independent variable.

Table 6 ANOVA Test

\begin{tabular}{llllll}
\hline Model (1) & Sum of Squares & Df & Mean Square & F & Sig. \\
\hline Regression & 179.757 & 2 & 89.878 & 435.207 & $.000^{\mathrm{b}}$ \\
Residual & 34.076 & 165 & 0.207 & & \\
Total & 213.832 & 167 & & & \\
\hline
\end{tabular}

Note. $a=$ Dependent Variable: SHP; $b=$ Predictors: (Constant), MA

Table 7 shows the standardized and unstandardized coefficients, significant level, Part Correlations and the t value. The factors of Market Assessment $(p=0.000$; Std. coefficients $=0.341)$ contribute significantly (Sig. is less than $5 \%$ ) to the sustainability of humanitarian projects with mean of probability equal to $34.1 \%$. Results reveal that market assessment has a significant impact on the sustainability of humanitarian projects. Therefore, hypothesis (H1) is supported. The findings are in line with the studies by Julliard (2018) and Levine (2017) who found that market assessment has a significant effect on sustainability.

Table 7 Regression Analysis

\begin{tabular}{lllllll}
\hline Model ( 1) & \multicolumn{2}{l}{$\begin{array}{l}\text { Unstandardized } \\
\text { Coefficients }\end{array}$} & $\begin{array}{l}\text { Standardized } \\
\text { Coefficients }\end{array}$ & T & Sig & $\begin{array}{l}\text { Part } \\
\text { Correlations }\end{array}$ \\
\hline & B & Std. Error & Beta & & \\
\hline (Constant) & -0.247 & 0.102 & & -2.426 & 0.016 \\
MA & 0.390 & 0.086 & 0.341 & 4.516 & 0.000 & 0.140 \\
\hline
\end{tabular}

Note. Dependent Variable: SHP

\section{Recommendations}

This study provides recommendations based on the research results, which try to guide the government and INGOs in Yemen to identify some of the important factors that may help to enhance the long run impacts of humanitarian projects. This will promote the efficiency of the projects funds, increase the target people, and reduce the rate of poverty and catastrophe among the Yemeni society especially in the current protracted crisis, which was exacerbated due to the lack of awareness among the Yemeni people, particularly those directly affected by it. According to the results of this study, the following recommendations are made.

- The organization should be equipped with the right tools, especially of the same context to conduct timely high quality market assessment of the Yemeni market in general and the market of the same context of 
their response before starting to think about any projects.

- Market assessment should be realigned with the type of response before the start of the project and to be regular at least bi annual to address all the requirement of Yemeni market to fulfill the people's needs.

- Market assessment should contain all the aspect that may lead to identify the requirement of humanitarian response with a deep focus on the vulnerable people context in which the INGO responds.

- Projects should focus on the result that may help to improve the long-lasting benefit of the people regardless of the immediate result or long time of the implementation.

- The market-based response should be applied and all the materials should be procured from the local markets, which help the markets to find jobs for the jobless people and consequently enhance the resilience and sustainability of the target people.

- INGOs should have fully trained staff members who have the capacity to conduct market analysis timely and quickly, especially in rapid response, so that the market-based approaches will be applied truly.

- Projects should enhance the capacity of the local people from different perspectives (economically and skillfulness).

\section{References}

Abila, S. (2020). An Analyses of Threats to the Realisation of the United Nations' Sustainable Development Goals Report 2019 in the Light of the Recent Report of the Global Futures (ie the World Wildlife Fund) on the Unfolding Trends on the Environment in Nigeria and the Globe-A Call for Sustained Global Action. JL Pol'y \& Globalization, 95, 38 .

Asian Enterprise Institute. (2013, January 1). Market Assessment (Market tool Kit). Retrieved from https://web.smu.edu.sg/spring/market-assessment/what-is-market-assessment/\#sp-content

BBC News, https://www.youtube.com/watch?v=1CmheyRVz7U\&list=ULhJPlvuqa6CU\&index=5777\&app=desktop

Betts, A., Bloom, L., Kaplan, J., \& Omata, N. (2014). Refugee Economies: Rethinking Popular Assumptions. Humanitarian Innovation Project, University of Oxford. Oxford. Saatavilla: http://www. rsc. ox. ac. uk/refugeeeconomies, luettu, 25, 2015.

Burns, N., \& Grove, S. K. (2010). Understanding nursing research-eBook: Building an evidence-based practice. Elsevier Health Sciences.

Center for Global Development. (2015). Doing Cash Differently. How Cash Transfers Can Transform Humanitarian Aid. Report of the High Level Panel on Humanitarian Cash Transfers. London: ODI. Retrieved 7 June 2016, from http://www.odi.org/publications/9876-cash-transfers-humanitarian-vouchers-aid-emergencies

CLP (2017), Global Framework for Action, Cash Learning Partnership. Available on: https://www.calpnetwork.org/publication/global-framework-for-

action/\#: : :text=This $\% 20$ framework $\% 20$ provides $\% 20 \mathrm{a} \% 20$ consolidated,response $\% 20$ during $\% 202015 \% 20 \mathrm{and} \%$ 202016.

DW. (2018). The arrow (where is the money) is targeting INGOs in Yemen. Humanitarian INGOs in Yemen (Arabic), 5.

Aid, H., \& Civil Protection department of the European Commission (2010). Rules and procedures applicable to property, supply, works and service contracts awarded within the framework of humanitarian actions financed by the European union.

Haavisto, I., \& Kovács, G. (2014). Perspectives on sustainability in humanitarian supply chains. Disaster Prevention and Management.

Hair, J. F., Anderson, R. E., Babin, B. J., \& Black, W. C. (2010). Multivariate data analysis: A global perspective (Vol. 7).

Julliard, H. (2018). Minimum standard for market analsysis. Swiss: Swiss Govrnment. Retrieved from https://reliefweb.int/report/world/minimum-standard-market-analysis-misma

Juillard, H., Mohiddin, L., Pechayre, M., Smith, G., \& Vince, R. (2016). The Influence of Market Support Interventions on Household Food Security: An evidence synthesis protocol.

Krejcie, R. V., \& Morgan, D. W. (1970). Determining sample size for research activities. Educational and psychological measurement, 30(3), 607-610. 
Krishna, A. (2013). Addressing the critical issues for successful international market penetration by Malaysian telecommunications firms.

Kunz, N., \& Gold, S. (2017). Sustainable humanitarian supply chain management-exploring new theory. International Journal of Logistics Research and Applications, 20(2), 85-104.

Levine, S. (2017). Markets in crises: the implications for humanitarian action. London: Overseas Development Institute. Retrieved from https://www.odi.org/publications/10888-markets-crises-implications-humanitarianaction

Lois and Chessex (2013). Austen, Lois and Sebastien Chessex, Minimum Requirements for Market Analysis in Emergencies, The Cash Learning Partnership, Oxford.

Mukeere, B. (2009). Basics of Market Analysis for Food Security. Available at SSRN 1370865.

Nutz, N. (2017). A Guide to Market-Based Livelihood Interventions for Refugees.

OCHA. (2018). Media Advisory - High-level pledging event for the humanitarian crisis in Yemen [Press release]. Geneva, Switzerland. Retrieved from https://reliefweb.int/report/yemen/media-advisory-high-level-pledgingevent-humanitarian-crisis-yemen.

OCHA (2020), Humanitarian Update 2020, https://reliefweb.int/sites/reliefweb.int/files/resources/May\%20Humanitarian_update_2020_Final.pdf

Okun, M. A. (2009). Factors affecting sustainability of donor funded projects in arid and semi-arid areas in Kenya; a case of Marsabit central district (Doctoral dissertation, Kenyatta University).

Sivakumaran, S. (2011). Market analysis in emergencies.

Sona, K. A study of the efficacy of IT Based Srvices in Management Educational Institutions.

Sphere Association. (2018). The Sphere Handbook. Geneva: British Library.

Sphere Association (Ed.). (2018). Sphere Handbook: Humanitarian Charter and Minimum Standards in Humanitarian Response. PRACTICAL ACTION.

Sustainable Development Group. (2019). Sustainable development goals report 2019. New York: UN. Retrieved from https://unstats.un.org/sdgs/report/2019/The-Sustainable-Development-Goals-Report-2019.pdf

Uma Sekaran. (2000). Research methods for business: A skill-building approach. John Wiley \& Sons.

USAID (2012) (U.S. Agency for International Development, 2012), Compliance and Oversight of Partner Performance, at http://www.usaid.gov/comp1iance, .

Vince, H. J. (2016). The influence of market support interventions on household food security. OXFORD, UK: OXFAM GB.

Weerawardena, J., McDonald, R. E., \& Mort, G. S. (2010). Sustainability of nonprofit organizations: An empirical investigation. Journal of World Business, 45(4), 346-356.

World Bank, (2005). Bruntland Commission report Analysis. World Bank press: New York.

Zikmund, W. G., Carr, J. C., \& Griffin, M. (2013). Business Research Methods (Book Only). Cengage Learning.

\section{Copyrights}

Copyright for this article is retained by the author(s), with first publication rights granted to the journal.This is an open-access article distributed under the terms and conditions of the Creative Commons Attributionlicense (https://creativecommons.org/licenses/by-sa/4.0/). 